\title{
Hydroalcoholic Extract of Crambe on Sitophilus zeamais Insects and Maize Seed Quality
}

\author{
Ana Paula Morais Mourão Simonetti ${ }^{1,2} \&$ Divair Christ $^{2}$ \\ ${ }^{1}$ Centro Universitário Assis Gurgacz, FAG, Cascavel, PR, Brazil \\ ${ }^{2}$ Universidade Estadual do Oeste do Paraná (UNIOESTE), Cascavel, PR, Brazil \\ Correspondence: Ana Paula Morais Mourão Simonetti, Universidade Estadual do Oeste do Paraná (UNIOESTE), \\ Cascavel, PR, Brazil. Tel: 55-45-3321-3947. E-mail: anamourao@fag.edu.br
}

Received: October 23, 2017

Accepted: November 22, 2017

Online Published: December 15, 2017

doi:10.5539/jas.v10n1p283

URL: https://doi.org/10.5539/jas.v10n1p283

\begin{abstract}
The objective of this work is to evaluate the insecticidal and attractiveness of concentrations of hydroalcoholic extract of crambe grains on Sitophilus zeamais, and its effect on the physiological quality of corn seeds. The experiments were conducted at the Laboratory of Entomology and Seeds of the Assis Gurgacz University Center, in Cascavel, PR. The evaluation of attractiveness and insecticidal effect were evaluated using DIC, with 4 treatments $(0,5,15$ and $25 \%$ extract concentration) and 10 or 5 replications, respectively, totaling 40 experimental plots for the insect attractiveness test and 20 Experimental plots for the test of the insecticidal effect. For the experiment on the physiological quality of corn seeds submitted to the extracts, a DIC was set up in a $4 \times 4$ factorial scheme, factor 1 being the storage time of the seeds $(0,30,60$ and 90 days) and factor 2 , the concentrations $(0,5,15$ and 25\%), with 4 replicates, totaling 64 plots. Data were submitted to ANAVA, and means adjusted to regression or submitted to the Tukey test at $5 \%$ of probability, using the statistical program ASSISTAT ${ }^{\circledR}$. The results evidenced the treatment with a hydroalcoholic extract in the concentration of $25 \%$ as the one with the highest insecticidal effect, and extract at $15 \%$ concentration yields a higher percentage of germination, normal seedlings, and mass of seedlings than the control. At $25 \%$ concentration, the extract do not negatively influence any of the parameters analyzed. Storage time above 60 days stimulates germination, mass and length of maize seedlings.
\end{abstract}

Keywords: Zea mays, insecticide, Crambe abyssinica, attractiveness

\section{Introduction}

Maize is produced in many continents and can be used in several ways, from human and animal nourishment to the high technology industry, in the production of films, biodegradable packaging, and other products. According to Paes (2006), about $70 \%$ of the world's maize production is destined to animal feed. In developed countries this figure may reach $85 \%$. However, only $15 \%$ of all world production is destined for human consumption, directly or indirectly.

Travaglia (2011) states that grains often need to be stored for more than a year due to off-seasons and drought periods. The purpose of storage is to preserve the characteristics and quality of the grains over time in order to meet the market demands. However, if storage conditions are not adequate the grains become susceptible to deterioration and exposed to possible contamination.

Seed or grain quality may be affected by several factors, including storage pests, such as Sitophilus zeamais, which may be responsible for the physical deterioration of the stored batch (Lorini Kryzanowski, França-Neto, \& Henning, 2010).

Improper storage conditions lead to severe attacks of storage pests, which might make these grains unfit for consumption (Michelraj \& Sharma, 2006).

Currently, storage pests are commonly controlled by applying chemical products, however, Barbosa (2004) states that the residues of these chemical insecticides can be found not only in the grains, but also in the processed products in different concentrations. Thus, according to Viebrantz, Radunz, and Dionello (2016), due to the need to improve food quality and safety, the use of chemical methods has been replaced by alternative methods. 
Crambe (Crambe abyssinica) is an oilseed that belongs to the brassicaceae family. It presents rapid growth and short cycle. It is highly tolerant to pests, which only attack the crop during the seedling phase. Some pests that have already been reported for attacking crambe crops are the Cabbage Aphid (Brevicoryne brassicae), Cucurbit Beetle (Diabrotica speciosa) and Agrotis sp. (Bezerra et al., 2011).

The brassica family has been studied due to the production of secondary metabolites, such as glucosinolates (Merah, 2015). Pitol, Broch, and Roscoe (2010) explain that crambe presents low incidence of pests due to the presence of glucosinolates. Pal Vig, Rampal, Thind, and Arora (2009) also mention studies that point out that this compound has several biological activities, such as protection against pathogens and weeds. Tsao, Peterson, and Coats (2002) suggest that remnants of plants that contain glucosinolates, when incorporated into the soil, can control soil pests.

Studies on crambe extracts have demonstrated its efficiency in controlling nematodes (Coltro-Roncato et al., 2016), whereas other studies incorporated crambe residues in soils colonized with nematodes (Nascimento, Jaime, G. E. Silva, A. R. Silva, \& Alves, 2016).

According to Pal Vig et al. (2009), glucosinolates accelerate insect respiration, which consequently increases their need for ATP while blocking its production. This leads to the exhaustion of energy sources and culminates in the insect's death.

The objective of this research was to evaluate the insecticidal effect and attractiveness of different concentrations of hydroalcoholic extract of crambe on Sitophilus zeamais, as well as its effect on the physiological quality of stored maize seeds throughout the storage period.

\section{Material and Methods}

This experiment was conducted at the Laboratory of Entomology of the Assis Gurgacz University Center in Cascavel, Paraná, Brazil, at a temperature of $25 \pm 2{ }^{\circ} \mathrm{C}$ and relative humidity of $60 \pm 5 \%$. The insects used in the tests were obtained from the insect farm kept in the laboratory, with maize kernels placed in containers measuring $8 \mathrm{~cm}$ in diameter $\times 6 \mathrm{~cm}$ in height. Grains of the maize hybrid AM 4003 were obtained from Melhoramento Agropastoril, a grain-producing company. Crambe grains were obtained from the experimental fields at the School Farm of the Assis Gurgacz Foundation University Center, Cascavel, Paraná, Brazil, in 2014, and stored away from light and heat.

The crambe grains were ground in an IKA A11 Basic 2500 1/min IP43 mill in order to obtain powder, which was mixed with $100 \mathrm{~mL}$ of the hydroalcohol composed of $50 \%$ water and $50 \%$ alcohol, homogenized in a blender in previously determined concentrations, and kept in a beaker with film and foil for light protection, for $48 \mathrm{~h}$.

\subsection{Evaluation of Repellency/Attractiveness on Sitophilus zeamais Insects}

The experiment was set up in a completely randomized design, consisting of 4 treatments (concentrations $0 \%$, $5 \%, 15 \%$ and $25 \%$ ) and 10 replications of each, totaling 40 experimental plots.

For the evaluation of the repellency on Sitophilus zeamais, two MDF feeding arenas measuring $45 \times 45 \times 3 \mathrm{~cm}$ were used, having a central hole with a diameter of $8 \mathrm{~cm}$ and four lateral holes with a diameter of $6 \mathrm{~cm}$ each. They were interconnected symmetrically by four $10-\mathrm{cm}$ paths that connected the central and lateral holes, all with a depth of $2 \mathrm{~cm}$, coated with contact paper and covered with perforated paper to allow aeration.

Ten grams of maize kernels were placed in each container. Container \#1 was the control (maize kernels only). Container \#2 had maize kernels mixed with $0.5 \mathrm{~mL}$ of hydroalcoholic extract of crambe at $5 \%$ concentration. Container \#3 had maize kernels mixed with $0.5 \mathrm{~mL}$ of hydroalcoholic extract of crambe at $15 \%$ concentration. Container \#4 had maize kernels mixed with $0.5 \mathrm{~mL}$ of hydroalcoholic extract of crambe at $25 \%$ concentration.

Ten Sitophilus zeamais insects were released into the central container of each arena. After 1 hour and 48 hours, the number of insects in each container was counted in order to assess the attractiveness at the first moment of exposure and two days later.

Data were subjected to analysis of variance (ANOVA) and means were fit to the regression in the statistical program ASSISTAT ${ }^{\circledR}$ version 7.7 (Silva \& Azevedo, 2016).

\subsection{Insecticide Evaluation}

The assay was performed on Petri dishes, in a completely randomized design consisting of 4 treatments, as follows: Treatment \#1 - control (distilled water); Treatment \#2 - hydroalcoholic extract of crambe at 5\% concentration; Treatment \#3 - hydroalcoholic extract of crambe at $15 \%$ concentration; and Treatment \#4 - 
hydroalcoholic extract of crambe at $25 \%$ concentration. There were also 5 replications of each, totaling 20 experimental plots.

Each Petri dish was lined with two sheets of germination test paper. One $\mathrm{ml}$ of distilled water or one $\mathrm{ml}$ of the hydroalcoholic extract of crambe was added to the Petri dishes with a syringe in the different concentrations determined. The dishes were then infested with 10 non-sexed adult insects of Sitophilus zeamais and sealed with film paper with microapertures to allow air to enter. The 20 Petri dishes were placed in a BOD chamber, at a temperature of $25 \pm 2{ }^{\circ} \mathrm{C}$, photoperiod of $14 \mathrm{hL}$ and relative humidity of $60 \pm 5 \%$.

The evaluations were carried out $12 \mathrm{~h}$ and $24 \mathrm{~h}$ after beginning the experiment by obtaining the number of dead insects. Data were subjected to ANOVA and means were fit to the regression in the statistical program ASSISTAT ${ }^{\circledR}$ version 7.7 (Silva \& Azevedo, 2016).

\subsection{Germination Test}

The germination test in maize kernels was conducted at the Seeds Laboratory of the Assis Gurgacz Foundation University Center, in Cascavel, Paraná, Brazil. The experiment was set up in a completely randomized design consisting of a $4 \times 4$ factorial scheme. Factor 1 was seed storage time $(0,30,60$ and 90 days), and factor 2 was the concentration of the hydroalcoholic extract of crambe $(0,5,15$ and $25 \%)$. There were 4 replications, totaling 64 experimental plots.

Each replication included 50 seeds of the maize hybrid AM 4003. The parameters evaluated were percentage of germination, percentage of normal seedlings, and seedling mass and length at day 7 after sowing (Brasil, 2009).

The data were subjected to analysis of variance and the means were compared by Tukey's test at $5 \%$ probability in the statistical program ASSISTAT ${ }^{\circledR}$ version 7.7 (Silva \& Azevedo, 2016).

\section{Results and Discussion}

Table 1 shows the analysis of variance of the regression of data related to the insecticidal action of the hydroalcoholic extract of crambe on Sitophilus insects after 12 and $24 \mathrm{~h}$ of exposure. The number of dead insects after $12 \mathrm{~h}$ of exposure fit the linear regression, whereas the number of dead insects after $24 \mathrm{~h}$ fit the cubic regression, both determined based on the $\mathrm{R}^{2}$.

Data transformation was necessary to determine the most adequate coefficient of variation, which is justified by Haddad and Vendramim (2000), who state that the transformation of data by using $\sqrt{x}$ is usual in entomology, since it homogenizes the experimental variance, which is a statistical requirement for the validation of the tests of significance and confidence intervals for the means of the treatments.

Table 1. Regression in the analysis of variance of the insecticidal action of different concentrations of hydroalcoholic extract of crambe on the insect S. zeamais, for $12 \mathrm{~h}$ and $24 \mathrm{~h}$, with transformation of using $\sqrt{x}$

\begin{tabular}{lll}
\hline Treatments & Number of dead insects after $12 \mathrm{~h}$ & Number of dead insects after $24 \mathrm{~h}$ \\
\hline F-statistics & 40.22 & 28.25 \\
CV $(\%)$ & 16.80 & 18.07 \\
L.R. & $*$ & n.s. \\
C.R. & n.s. & $*$ \\
\hline
\end{tabular}

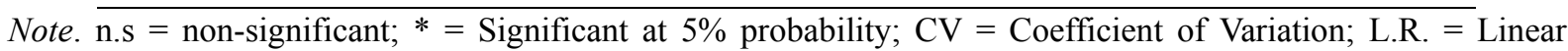
Regression; C.R. $=$ Cubic Regression.

Figure 1 shows the percentage of dead insects as the concentration of hydroalcoholic extract of crambe increased. After 12 hours of exposure, the extracts provided approximately $35 \%$ of dead insects, whereas in the control, all insects remained alive. These results point out that the alternative control of these insects is possible. Some studies have demonstrated the resistance of Sitophilus zeamais to chemical insecticides that have not yet been released for the control of storage pests in Brazil, such as indoxicarb (Haddi, Mendonça, Santos, Guedes, \& Oliveira, 2015), thus, having an alternative method for controlling them is necessary. 


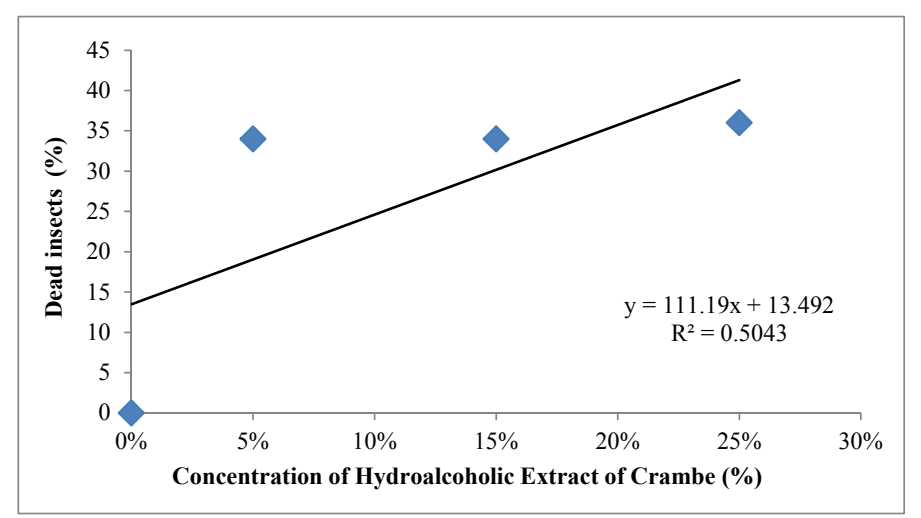

Figure 1. Evaluation of the insecticidal action after $12 \mathrm{~h}$ of exposure of Sitophilus zeamais to different concentrations of hydroalcoholic extracts of crambe under controlled conditions of temperature and photoperiod

Nascimento, Diniz Filho, Mesquita, Oliveira, and Pereira (2008) found 96 to 100\% of dead Sitophilus insects exposed to Tagetes patula extract in vapor form. Restello, Menegatt, and Mossi (2009) studied the effect of the essential oil of T. patula on Sitophilus mortality and found $100 \%$ of dead insects. Silva, Melo, Pessoa, Almeida, and Gomes (2012) observed a raise in Sitophilus mortality as the rates of Momordica charantia (L.) extract increased, reaching $100 \%$ mortality when applying $10 \mathrm{~mL}$ of the extract.

Figure 2 shows the percentage of dead insects after 24 hours of exposure to different concentrations of hydroalcoholic extracts of crambe. The data did not fit the regression. In the control, $100 \%$ of the insects remained alive. In the treatment with the extract at $5 \%$ concentration, about $65 \%$ of the insects died. This number decreased to $45 \%$ when concentration was $15 \%$ and increased to about $60 \%$ when extract concentration was $25 \%$.

According to Glaser (1996), the increase in Sitophilus mortality due to the presence of crambe extract happens because the glucosinolates found in brassicas might act as control for pests such as nematodes, flies, maggots and mites.

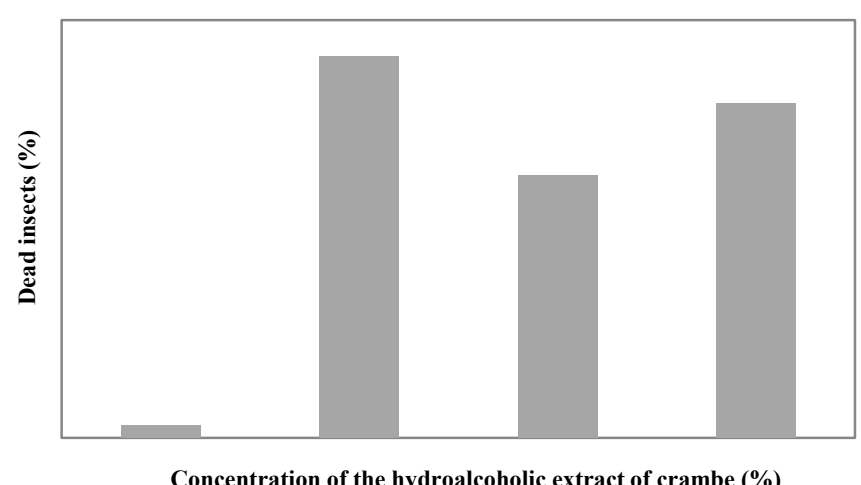

Figure 2. Analysis of the insecticide action on Sitophilus zeamais after 24 hours of exposure to different concentrations of hydroalcoholic extract of crambe under controlled conditions of temperature and photoperiod

Table 2 shows the insects' behavior in the feeding arena containing maize kernels with the 4 different concentrations of hydroalcoholic extract of crambe, at $1 \mathrm{~h}$ and $48 \mathrm{~h}$ of exposure. Just as the insects were exposed, it was observed that $44.2 \%$ of them were attracted to maize kernels with no addition of hydroalcoholic extract, what differs statistically from the other treatments. Concurrently, $23 \%$ of the insects were attracted to kernels with extract at $15 \%$ concentration, $19.2 \%$ were attracted to kernels with extract at $5 \%$ concentration and $15 \%$ were attracted to kernels with extract at $25 \%$ concentration, showing no statistical difference among treatments. 
After $48 \mathrm{~h}$ of exposure, Treatment \#1 remained as the most attractive to insects, with 30\% preference; however, it was statistically equal to Treatment \#3, with $25.4 \%$ preference, and Treatment \#4, with $28 \%$ preference. Treatment \#2 attracted only $16.6 \%$ of the insects, what differs statistically from the control (T1). Cruz, Sousa, Medeiros, Silva, and Gomes (2012) studied the action of different essential oils in the control of Sitophilus zeamais insects and concluded that lavender oil had the best effect in repelling weevils from maize. Nonetheless, further research is required in order to establish the ideal concentration.

Table 2. Percentage of Sitophilus zeamais insects attracted to maize with different concentrations of hydroalcoholic extract of crambe, in a free-choice feeding arena, assessed at $1 \mathrm{~h}$ and $48 \mathrm{~h}$ of exposure

\begin{tabular}{lll}
\hline \multirow{2}{*}{ Treatment } & \multicolumn{2}{c}{$\%$ Attracted Insects } \\
\cline { 2 - 3 } & $1 \mathrm{~h}$ & $48 \mathrm{~h}$ \\
\hline T1 $(0 \%)$ & $44.2 \mathrm{a}$ & $30.0 \mathrm{a}$ \\
$\mathrm{T} 2(5 \%)$ & $19.2 \mathrm{~b}$ & $16.6 \mathrm{~b}$ \\
$\mathrm{~T} 3(15 \%)$ & $23.0 \mathrm{~b}$ & $25.4 \mathrm{ab}$ \\
$\mathrm{T} 4(25 \%)$ & $15.0 \mathrm{~b}$ & $28.0 \mathrm{ab}$ \\
\hline CV $(\%)$ & 32.79 & 32.48 \\
\hline MSD & 12.24 & 14.8 \\
\hline
\end{tabular}

Note. Means followed by the same letter in the columns are not significantly different (Tukey, $\mathrm{P}<0.05)$.

Figure 3 shows that the percentage of insects attracted to maize kernels with hydroalcoholic extract of crambe (45\% attracted to control) after $1 \mathrm{~h}$ of exposure reduced with higher concentrations of the extract; only $17 \%$ of the insects were attracted to treatment $\# 4-25 \%$ extract concentration. Fernandes and Favero (2014) studied the attractiveness/repellence of the essential oil of Schinus molle on Sitophilus zeamais at $1 \mathrm{~h}$ and $24 \mathrm{~h}$ of exposure and observed repellent action of the lethal concentrations of 5 and $10 \mathrm{ppm}$.

Almeida, Silva Junior, Silva, Lino, and Silva (2012) studied the control of Sitophilus zeamais with a hydroalcoholic extract made from pinecone and black pepper and reported that the infestation percentage of the insect-pest on maize seeds decreased with higher concentrations of the extract, what was corroborated in this experiment.

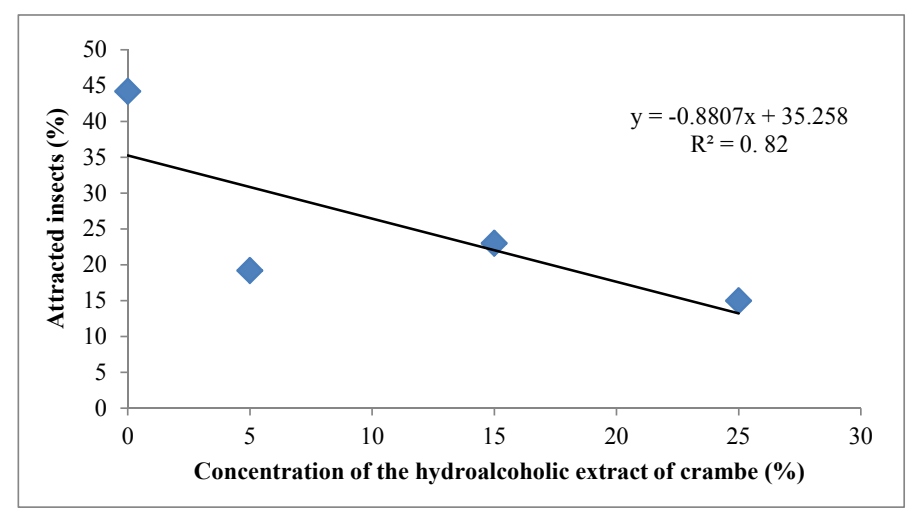

Figure 3. Percentage of Sitophilus zeamais attracted to maize kernels treated with different concentrations of hydroalcoholic extract of crambe, after $1 \mathrm{~h}$ of exposure in a free-choice feeding arena

Concerning to preference, after $48 \mathrm{~h}$ of exposure (Figure 4), 30\% of the insects were attracted to maize kernels in the control treatment. This percentage was lower in treatments \#2 and \#3 and showed a tendency of increase in treatment \#4 - 25\% extract concentration (28\% of insects attracted). Guimarães et al. (2014) noticed that aqueous extracts from seeds of Capsicum baccatum showed repellent activity on maize weevils whereas the alcoholic extract from the pulp of Capsicum baccatum showed 34.6\% attractiveness on adult Sitophilus zeamais insects. Such result is similar to those found in this experiment, which indicates that the substances released in alcohol might be different than those released in water. 


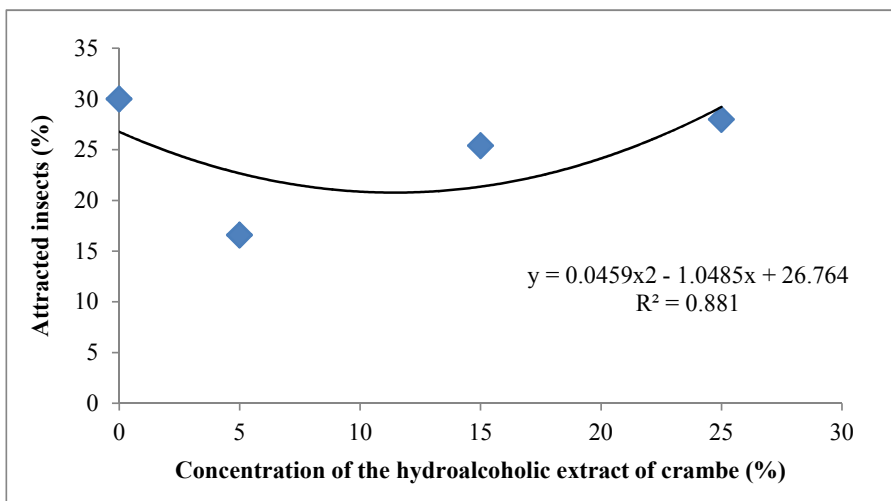

Figure 4. Percentage of Sitophilus zeamais attracted to maize kernels treated with different concentrations of hydroalcoholic extract of crambe, after $48 \mathrm{~h}$ of exposure in a free-choice feeding arena

Table 3 shows the percentage of germination and normal seedlings, mass of 10 seedlings $(\mathrm{g})$ and seedling length $(\mathrm{cm})$ of maize kernels treated with different concentrations of hydroalcoholic extract of crambe $(0,5,15$ and $15 \%)$ under different storage times (0, 30, 60 and 90 days).

The coefficients of variation found in every parameter assessed point to the homogeneity of the data, since the percentage of germination, normal maize seedlings and mass of 10 seedlings (g) presented CV below 10\% (3.99, 4.69 and $6.12 \%$, respectively) whereas seedling length had a $14.18 \%$ CV. According to Gomes (2002), coefficients of variation up to $10 \%$ suggest low heterogeneity, that is, the data is reliable. Ten to $20 \%$ represent medium homogeneity.

Table 3. Percentage of germination and normal seedlings, mass of 10 seedlings $(\mathrm{g})$ and seedling length $(\mathrm{cm})$ of maize kernels treated with different concentrations of hydroalcoholic extract of crambe, under different storage times and controlled conditions

\begin{tabular}{|c|c|c|c|c|}
\hline Treatment & Germination at 7 days ( $\%)$ & Normal seedlings (\%) & Mass of 10 seedlings $(\mathrm{g})$ & Seedling length $(\mathrm{cm})$ \\
\hline \multicolumn{5}{|c|}{ Storage time $(T)$} \\
\hline 0 day & $88.00 \mathrm{~b}$ & $88.00 \mathrm{a}$ & $4.48 \mathrm{~d}$ & $3.30 \mathrm{c}$ \\
\hline 30 days & $92.75 \mathrm{a}$ & $87.62 \mathrm{a}$ & $6.03 \mathrm{c}$ & $12.09 \mathrm{~b}$ \\
\hline 60 days & $91.50 \mathrm{a}$ & $85.50 \mathrm{a}$ & $7.64 \mathrm{a}$ & $16.16 \mathrm{a}$ \\
\hline 90 days & $91.75 \mathrm{a}$ & $85.87 \mathrm{a}$ & $6.77 \mathrm{~b}$ & $16.21 \mathrm{a}$ \\
\hline \multicolumn{5}{|c|}{ Extract concentration $(C)$} \\
\hline $0 \%$ & $90.00 \mathrm{~b}$ & $84.5 b$ & $6.01 \mathrm{~b}$ & $11.22 \mathrm{a}$ \\
\hline $5 \%$ & $91.75 \mathrm{ab}$ & $87.37 \mathrm{ab}$ & $6.11 \mathrm{~b}$ & $12.03 \mathrm{a}$ \\
\hline $15 \%$ & $93.50 \mathrm{a}$ & $90.75 \mathrm{a}$ & $6.47 \mathrm{a}$ & $12.10 \mathrm{a}$ \\
\hline $25 \%$ & $88.75 b$ & $84.37 \mathrm{~b}$ & $6.33 \mathrm{ab}$ & $12.40 \mathrm{a}$ \\
\hline $\mathrm{CV}(\%)$ & 3.99 & 4.69 & 6.12 & 14.18 \\
\hline MSD & 3.41 & 3.83 & 0.36 & 1.59 \\
\hline \multicolumn{5}{|l|}{ F-statistics } \\
\hline T-factor & * & ns & $*$ & $*$ \\
\hline $\mathrm{C}$-factor & * & $*$ & * & ns \\
\hline $\mathrm{T} * \mathrm{C}$ & ns & * & * & ns \\
\hline
\end{tabular}

Note. ${ }^{*}$ Significant at $5 \%$ probability; ns: non-significant; $\mathrm{CV}(\%)=$ Coefficient of variation. MSD $=$ minimum significant difference.

Concerning to the germination percentage, there was no interaction between the factors storage time and extract concentration, what shows the independence of the factors analyzed. Regarding the storage time, at 0 day the germination rate $(88 \%)$ was statistically inferior to those under other storage times, all above $90 \%$ and statistically equal. 
In relation to the extract concentration, at $15 \%$ there was higher germination than at $0 \%$ and $25 \%$, despite being statistically equal to the treatment with $5 \%$ extract concentration, what demonstrates that the extract stimulates maize seed germination. However, Brow and Morra (2005) reported that plants that have glucosinolates might affect successive crops. Some reports state that the presence of brassicas reduces the establishment of seedlings of different crops. Brassica napus straw, for instance, decreases the emergence of wild oat (Avena sterilis) and black mustard (Brassica nigra) and inhibits the germination of grasses and broccoli.

As for seedling length, there was no interaction among the factors and the extract concentration did not influence this parameter. Such result is in accordance with those of Renosto, Vonz, Paiva, Marostica, and Viecelli (2014), who studied static extracts of crambe at 2.5 and $10 \%$ concentration and did not find significant difference in the length of the aerial part of the maize plants.

Storage time significantly influenced length. The longer the kernels exposed to the extracts were stored, the longer the length of the seedlings. Thus, it is concluded that storage time positively influences growing.

Table 4 shows the relationship between storage time and different concentrations of the hydroalcoholic extract of crambe and its effect on the normality of the maize seedlings. Regardless of the storage time, the percentage of normal seedlings was statistically the same. However, if each storage time is analyzed separately, only at 0 day the extract concentration did not influence the percentage of normal seedlings. At 30 and 60 days, the percentage of normal seedlings was higher than in the control only at $15 \%$ concentration ( $94.5 \%$ and $91.5 \%$, respectively). Menegusso and Simonetti (2015) studied aqueous extracts made from the root and aerial part of crambe plants and found that at $10 \%$ concentration, the number of normal maize seedlings was higher than in the control, however, at higher concentrations ( 20 and 30\%), the number of normal seedlings decreased.

After 90 days of storage, the percentage of normal seedlings was statistically equal to that of the control at every concentration, except at $25 \%$, which was lower (Table 4).

Table 4. Relationship between storage time and concentrations of the hydroalcoholic extract of crambe and its effect on the percentage of normal maize seedlings under controlled conditions

\begin{tabular}{lllll}
\hline \multirow{2}{*}{ Storage time $(\mathrm{T})$} & \multicolumn{4}{c}{ Hydroalcoholic extract of crambe concentration (\%) } \\
\cline { 2 - 5 } & $0 \%$ & $5 \%$ & $15 \%$ & $25 \%$ \\
\hline 0 day & $86.0 \mathrm{aA}$ & $90.0 \mathrm{aA}$ & $90.0 \mathrm{aA}$ & $86.0 \mathrm{abA}$ \\
30 days & $84.0 \mathrm{aB}$ & $84.5 \mathrm{aB}$ & $94.5 \mathrm{aA}$ & $87.5 \mathrm{aAB}$ \\
60 days & $80.5 \mathrm{aB}$ & $85.5 \mathrm{aAB}$ & $91.5 \mathrm{aA}$ & $84.5 \mathrm{abAB}$ \\
90 days & $87.5 \mathrm{aA}$ & $89.5 \mathrm{aA}$ & $87.0 \mathrm{aAB}$ & $79.5 \mathrm{bB}$ \\
\hline
\end{tabular}

Note. Same lowercase letter in the same column and same uppercase letter in the same row are not significantly different (Tukey, $\mathrm{P}<0.05$ ).

Table 5 depicts the relationship between storage time and extract concentration as well as its effect on the mass of 10 seedlings seven days after sowing. At 60 days of storage, regardless of the concentration to which the maize kernels were exposed, the mass of 10 seedlings was higher than in any other storage time, except at $0 \%$ and 90 days, which was statistically equal to the mass at 60 days of storage.

The extract concentration did not significantly influence the mass of 10 seedlings at 0 or 90 days of storage, however, it influenced at 30 and 60 days. The best result was achieved at $15 \%$ concentration and 30 days of storage. Such results differ from what was found in experiments using crambe hay over maize, in which the researchers reported a reduction in the mass of the aerial part of maize plants (Spiassi, Fortes, Pereira, Senem, \& Tomazoni, 2011). 
Table 5. Relationship between storage time and concentration of the hydroalcoholic extract of crambe and its effect on the mass of 10 maize seedlings under controlled conditions

\begin{tabular}{lllll}
\hline \multirow{2}{*}{ Storage time (T) } & \multicolumn{4}{c}{ Hydroalcoholic extract of crambe concentration (\%) } \\
\cline { 2 - 5 } & $0 \%$ & $5 \%$ & $15 \%$ & $25 \%$ \\
\hline 0 day & $4.62 \mathrm{cA}$ & $4.45 \mathrm{dA}$ & $4.55 \mathrm{cA}$ & $4.30 \mathrm{dA}$ \\
30 days & $5.62 \mathrm{bB}$ & $5.75 \mathrm{cB}$ & $6.85 \mathrm{bA}$ & $5.90 \mathrm{cB}$ \\
60 days & $7.15 \mathrm{aB}$ & $7.67 \mathrm{aAB}$ & $7.80 \mathrm{aAB}$ & $7.92 \mathrm{aA}$ \\
90 days & $6.65 \mathrm{aA}$ & $6.55 \mathrm{bA}$ & $6.67 \mathrm{bA}$ & $7.20 \mathrm{bA}$ \\
\hline
\end{tabular}

Note. Same lowercase letter in the same column and same uppercase letter in the same row do not differ among themselves at 5\% significance by Tukey's test.

In summary, besides making maize kernels less attractive to Sitophilus insects, the hydroalcoholic extract of crambe also improved the germination parameters of the stored maize seeds, what indicates the feasibility of the development of a hydroalcoholic extract of crambe-based product.

\section{Conclusions}

Considering the proposed goals and the results obtained in this experiment, it is concluded that:

$>\quad$ The hydroalcoholic extract of crambe at 25\% concentration applied on maize kernels results on an attractiveness rate $(28 \%)$ statistically equal to that of the control treatment $(30 \%)$ but on a higher mortality rate $(60 \%-0 \%)$.

$>\quad$ Concerning to the parameters related to the quality of the maize seeds, the hydroalcoholic extract of crambe at $15 \%$ concentration yields a higher percentage of germination, normal seedlings, and mass of 10 seedlings than the control. At $25 \%$ concentration, the extract do not negatively influence any of the parameters analyzed.

$>$ Storage time above 60 days stimulates germination, mass and length of maize seedlings.

\section{References}

Almeida, F. A. C., Silva Junior, P. J., Silva, J. F., Lino, T. F. L., \& Silva, R. G. (2012). Infestação e germinação em sementes de milho tratadas com extratos de Piper nigrum. e Annona squamosa. Revista Brasileira de Produtos Agroindustriais, Campina Grande, 14(Especial), 457-471. https://doi.org/10.15871/1517-8595/ rbpa.v14nEspecialp457-471

Barbosa, L. C. A. (2004). Os pesticidas, o homem e o meio ambiente (p. 215). Viçosa: Universidade Federal de Viçosa.

Bezerra, R. A., Cucolo, F. G., Lemke A. P., Silva, H. H. M., Mauad, M., \& Mussury, R. S. (2011). Ocorrência de insetos na cultura do Crambe (2nd ed., p. 2). Dourados-MS: Programa de Pós Graduação em Entomologia e Conservação da Biodiversidade, UFGD. Boletim de Entomologia Agroecológica, Insetos Associados a Culturas Oleaginosas.

Brasil. (2009). Regras para Análise de Sementes. Brasília, DF: Ministério da Agricultura, Pecuária e Abastecimento.

Brown, J., \& Morra, M. J. G. (2005). Glucosinolate. Containing seed meal as a soil amendment to control plant pests. Moscow. https://doi.org/10.2172/15016728

Coltro-Roncato, S., Stangarlin, J. R., Kuhn, O. J., Gonçalves, E. D. V., Dildey, O. D. F., Rissato, B. B., ... Webler, T. F. B. (2016). Nematicidal effect of Crambe abyssinica leaf extracts to Meloidogyne javanica on tomato. African Journal Agricultural Research, 11(32), 3004-3011. https://doi.org/10.5897/AJAR2016.11258

Cruz, C. S. A., Sousa, F. C., Medeiros, M. B., Silva, L. M. M., \& Gomes, J. P. (2012). Interferência de óleos essenciais na preferência de Sitophilus Zeamais (coleoptera: curculionidae) em grãos de milho. Revista Verde, Mossoró, 7(3), 187-193.

Fernandes, E. T., \& Favero, S. (2014). Óleo essencial de Schinus molle L. para o controle de Sitophilus zeamais Most.1855 (Coleoptera: Curculionidae) em milho. Rev. Bras. de Agroecologia, Porto Alegre, 9(1), $225-231$.

Glaser, L. K. (1996). Crambe: An economic assessment of the feasibility of providing multiple-peril crop insurance. Economic Research Service for the Risk Management Agency, Federal Crop Insurance Corporation. 
Gomes, F. P. (2002). Curso de estatística experimental (15th ed.). Piracicaba, SP: FEALQ.

Guimarães, S. S., Potrich, M., Silva, E. R. L., Wolf, J., Pegorini, C. S., \& Oliveira, T. M. (2014). Ação repelente, inseticida e fagoinibidora de extratos de pimenta dedo-de-moça sobre gorgulho do milho. Arq. Inst. Biol., São Paulo, 81(4), 322-328. https://doi.org/10.1590/1808-1657000172013

Haddad, M. L., \& Vendramim, J. D. (2000). Comparação de porcentagens observadas com casos extremos de 0 e 100\%. Anais da Sociedade Entomológica do Brasil, Piracicaba, 29(4), 50-55. https://doi.org/10.1590/ S0301-80592000000400027

Haddi, K., Mendonça, L. P., Santos, M. F., Guedes, R. N. C., \& Oliveira, E. E. (2015). Metabolic and behavioral mechanisms of indoxacarb resistance in Sitophilus zeamais (Coleoptera: Curculionidae). Journal of Economic Entomology, 1(1), 362-369. https://doi.org/10.1093/jee/tou049

Lorini, I., Kryzanowski, F. C., França-Neto, J. B., \& Henning, A. A. (2010). Principais pragas e métodos de controle em sementes durante armazenamento (Circular Técnica, 73). Série Sementes. Londrina: Embrapa.

Menegusso, F. J., \& Simonetti, A. P. M. M. (2015). Alelopatia do crambe sobre o milho. Revista Thêma et Scientia, Cascavel, 5(2), 169-174.

Merah, O. (2015). Genetic variability glucosinolates in seed of Brassica juncea interest in mustard condiment. Hindawi Publishing Corporation Journal of Chemistry, 2, 6-8.

Michelraj, S., \& Sharma, R. K. (2006). Fumigant toxicity of nem formulations against Sitophilus oryzae and Rhyzopertha dominica. Journal of Agricultural Technology, 2(1), 1-16.

Nascimento, D. D., Jaime, D. T. S., Silva, G. E., Silva, A. R., \& Alves, G. C. S. (2016). The role of Crambe abyssinica in the control of Heterodera glycines (Thylenchida: Heteroidae). African Journal Agricultural Research, 11(25), 2245-2249. https://doi.org/10.5897/AJAR2016.10947

Nascimento, F. J., Diniz Filho, E. T., Mesquita, L. X., Oliveira, A. M., \& Pereira, T. F. C. (2008). Extractos vegetables en el control de plagas. Revista Verde, Pombal, 3, 1-5.

Paes, M. C. D. (2006). Aspectos físicos, químicos e tecnológicos do grão de milho (Circular Técnica, 75). Sete Lagoas: Embrapa.

Pal Vig, A., Rampal, G., Thind, T. S., \& Arora, S. (2009). Bio-protective effects of glucosinolates - a review. Food Science and Technology, 42, 1561-1572. https://doi.org/10.1016/j.lwt.2009.05.023

Pitol, C., Broch, D. L., \& Roscoe, R. (2010). Tecnologia e produção: Crambe 2010 (p. 60). Maracaju, Fundação MS.

Renosto, A., Vonz, K. M., Paiva, F. F., Marostica, T. F., \& Viecelli, C. A. (2014). Efeitos alelopáticos do extrato de crambe no desenvolvimento inicial de milho. Revista Cultivando o Saber, Cascavel, 7(2), 176-181.

Restello, R. M., Menegatt, C., \& Mossi, A. J. (2009). Efeito do óleo essencial de Tagetes patula L. (Asteraceae) sobre Sitophilus zeamais Motschulsky (Coleoptera, Curculionidae). Revista Brasileira de Entomologia, Curitiba, 53(2), 304-307. https://doi.org/10.1590/S0085-56262009000200015

Silva, F. A. S., \& Azevedo, C. A. V. (2016). The Assistat software version 7.7 and its use in the analysis of experimental data. African Journal Agricultural Research, 11(39), 3733-3740. https://doi.org/10.5897/ AJAR2016.11522

Silva, J. F., Melo, B. A., Pessoa, E. B., Almeida, F. A. C., \& Gomes, J. P. (2012). Bioatividade do extrato de Momordica charantia L. sobre Sitophilus zeamais Motschulsky 1885 (Coleoptera: Curculionidae). Revista Verde, Pombal, 7(2), 179-183.

Spiassi, A., Fortes, A. M. T., Pereira, D. C., Senem, J., \& Tomazoni, D. (2011). Alelopatia de palhadas de coberturas de inverno sobre o crescimento inicial de milho. Semina: Ciências Agrárias, Londrina, 32(2), 577-582. https://doi.org/10.5433/1679-0359.2011v32n2p577

Travaglia, D. P. (2011). Crescimento de aspergillus flavus e produção de aflatoxinas em grãos de milho armazenados sob diferentes temperaturas (2011. 64 f. Dissertação, Mestrado em Engenharia Agrícola, Universidade Federal de Viçosa, Viçosa).

Tsao, R., Peterson, C. J., \& Coats, J. R. (2002). Glucosinolate breakdown products as insect fumigants and their effect on carbon dioxide emission of insects. BMC Ecology, 2(5), 2-7. 
Viebrantz, P. C., Radunz, L. L., \& Dionello, G. (2016). Mortality of insects and quality of maize grains in hemetical and non-hermetical storage. Revista Brasileira de Engenharia Agrícola e Ambiental, 20(5), 487-492. https://doi.org/10.1590/1807-1929/agriambi.v20n5p487-492

\section{Copyrights}

Copyright for this article is retained by the author(s), with first publication rights granted to the journal.

This is an open-access article distributed under the terms and conditions of the Creative Commons Attribution license (http://creativecommons.org/licenses/by/4.0/). 